Etikonomi

Volume 16 (2), Oktober 2017

P-ISSN: 1412-8969; E-ISSN: 2461-0771

Page 187 - 206

\title{
Religiosity and Entrepreneurial Intention
}

\author{
Buddi Wibowo \\ Universitas Indonesia \\ buddi.wibowo@ui.ac.id
}

\begin{abstract}
Religion and economic activities relationship is an evolving research topic in economics. Secular world-view usually put a side religiosity as just one of non-economic factors. However, religiosity is an important individual characteristic that has significant influence in shaping daily life decisions. Entrepreneurial intentions among undergraduates students need deeper study in order to reveal entrepreneurial intention formation model, intention determinant variables, how those variables interact each other, and how individual religiosity affect intention formation process and intention strength level. Based on Structural Equation Model, personal attitudes and social norms are the most important variables influencing entrepreneurial intentions, besides perceived behavioral control. These three variables are the most important entrepreneurial intentions determinant variable that direcly are influenced by personal beliefs about these factors. Religiosity plays an important role in entrepreneurial intention. Empirical test show that religious student group has stronger personal attitude towards entrepreneurial activity dan perceived behavior control compared to irreligious group.
\end{abstract}

Keywords: enterpreneurial intention, beliefs, attitudes, religiosity

\begin{abstract}
Abstrak
Hubungan antara agama dan aktivitas ekonomi merupakan sebuah topik riset yang berkembang pesat di bidang ekonomi. Cara pandang sekuler biasanya menempatkan religiusitas hanya sebagai salah satu dari sekian banyak faktor non ekonomi. Namun sudah diterima secara luas babwa religiusitas adalah sebuah karakteristik individual yang memiliki peran dan dammpak yang sangat besar dalam pengambilan keputusan sehari-hari. Niat untuk berwirausaha di kalangan mahasiswa memerlukan penelitian yang lebih mendalam untuk dapat mengungkap lebih jelas model pembentukan niat berwirausaha, variabelvariabel penentu niat, dan bagaimana semua variabel tersebut berinteraksi dan bagaimana religiusitas individual mempengarubi proses pembentukan niat dan kekuatan niat yang akbirnya terbentuk. Dengan menggunakan analisis Structural Equation Model (SEM) diperoleh kesimpulan bahwa sikap personal dan norma sosial menjadi variabel yang paling mempengarubi pembentukan niat, di samping perceived behavioral control. Tiga variabel ini merupakan determinan terpenting dari niat berwirausaha dan etiganya secara langsung dipengarubi oleh personal beliefs atas faktor-faktor tersebut. Religiusitas terbukti memainkan peran yang penting dalam proses pembentukan niat berwirausaha. Uji empiris menunjukkan kelompok mahasiswa yang religius memiliki sikap personal yang lebib baik terbadap aktivitas wirausaha dan memiliki kepercayaan diri yang lebih baik dibandingkan dengan kelompok yang tidak religius.
\end{abstract}

Kata kunci: niat berwirausaha, kepercayaan, sikap, religiusitas

Received: May, 26, 2017; Revised: June 19, 2017; Approved: July 10, 2017 
Religiosity and Entrepreneurial Intention

Buddi Wibowo

\section{INTRODUCTION}

Research on religion and religiousity impact to economy has increased considerably in recent decade. Deneulin and Rakodi (2010) give a good review of increasing attention on the link between religiosity and economic development. Many researchers stated Weber (1905) was the first scholar who identify religion significant role in economic performance of a community. Weber has an opposite view against Marx (1844) who stated religions are always in opposite position to economic advancement. Marx said:

"The grounds of the unreligious critique is man made religion, religion does not make man... Religious misery is, by one side, an expression of the real misery. Religion is the exhausted creature's sigh, the state of animus of a heartless world, the spirit of spiritless situations. Religion is the people's opium."

In his classic "The Protestant Ethic and the Spirit of Capitalism," Weber attributes the emergence of the spirit of capitalism in European society to the development of a Protestant ethic. Weber's Protestant ethic results from the interaction of the doctrine of salvation and the concept of goodworks. According to Weber, It was Luther who decisively altered the Christian concept of good works by prescribing the "fulfillment of duties in worldly affairs as the highest form which the moral activity of the individual could assume" (Weber, 1905)

Marx's theoretical doctrinal view of the world and its direct opposition to Weber's sociological observations encouraged enormous research that attempted to test empirically the influence of religion and religiosity to economic growth. Barro and McCleary (2003) examined the impact of religion on economic growth by using data from the World Value Survey (WVS). Barro and McCleary (2003) measured religiosity by using a survey of attendance at religious events, beliefs or faith in God, hell, surges, and the final day. They found some aspects of faith are positively associated with economic growth but specifically for attendance at a religious event does not have a significant relationship. Guiso et.al. (2003) using cross-country data from WVS also, find religious beliefs are conducive to higher income and income growth and Christian religions are more positively associated with economic growth. Pryor (2007) find that Islam, and in some specifications, Confucianism, are positively associated with per capita income growth. Alkire (2006), using cross-country and within-country data, rejects the null hypothesis that religion is uncorrelated with economic performance in a country.

Some expert stated religion could affect economic performance through various channels. Alkire (2006), points out that religious beliefs provide strong incentives to follow 
moral values such as trust, honesty, benevolence, and restraint from violence. All of that moral value is an evitable prerequisite to be success in a business. Deneulin and Rakodi (2010) show that all religions work to instill certain values, morals, and behaviors in their followers and these values, beliefs, and morals are seen in most aspects of human behavior. All religions emphasize supernatural monitoring and this leads adherents to be trustworthy, truthful, honest, and ethical (Habermas, 2006). Religious people are discouraged from engaging in activities such as divorce, abortion, and non-payment of debt, treating these activities as sinful. Religious people tend to have good traits and trustworthy those are the highest value of asset in world of business (Deneulin and Rakodi, 2010)

Religious commitments also lead to higher social capital in a community. Muller (2009) argues that trust is valued more higher in societies that have dense networks of civic engagement. These networks include neighborhood associations, sports clubs, choral societies, and political parties. Religious institutions and religious service attendance are often cited as sources of social capital (Deneulin and Rakodi, 2010, and Muller, 2009). This form of capital has been viewed as a vehicle for improving individuals' well being and for discouraging free riding and shirking.

Religiosity connects an individual to a community and this connection promotes the well being of that particular individual. Forms of religious social capital with direct economic implications include volunteer labor for community activities; donations to public causes, subsidized educational facilities, and economic enterprises belong to certain religious groups. Religion can promote social activities thereby increasing social interaction, and that in turn will promote social capital.

According to Pryor (2007), religiosity may help reduce information and transaction costs by promoting trust, information sharing, and voluntary labor. When transaction costs and the costs of gathering and disseminating information are decreased, more exchange will take place, it is easier to create a new business. Conversely the lack of religious qualities results in demands for more external controls, such as, tougher law enforcement and security systems, monitoring and enforcement. Religious institutions are known to monitor the behavior of their members and sometimes reward high levels of loyalty, and punish inappropriate behavior. Members of these institutions monitor, give advice, and encourage fellow members to abide by institutions.

One of the effects of religiosity on economic growth is large number of independent entrepreneurial activities. In the context of Islamic societies, such as the 
Religiosity and Entrepreneurial Intention

Buddi Wibowo

Islamic community in Indonesia, the desire to be financially independent usually motivated by the figure of the Prophet Muhammad himself who was quite successful merchant in his young age. In some hadith of the Prophet Muhammad, he even advocated for trade which he described as a profession that has the most lucrative and extensive sustenance. The entry of Islam into Indonesia in general is also related to the business activities that has important influence on unique religious nuances of Indonesian Muslims who prioritizes harmony, peace, and free exchange of ideas. History of the entry Islam into Indonesia, according to some experts started from the interaction of some local population with muslim traders from India and Persia. Santri, a islamic society which has strong islamic aspirations in Indonesia usually have prominent entrepreneurial spirit. The first indigenous organization and also the largest mass organization in Indonesia which was established independently by indigenous leaders to fight for the fate of native Indonesia during the colonial period is Sarikat Dagang Islam (Islamic Trade Association). Sarikat Dagang Islam (SDI) fully oriented at improving the economic fate of Indonesia indigenous people. SDI also functioned as trading forum and commercial networks of native muslim merchants. The huge members and its influence within the Indonesian Muslim community, Sarikat dagang Indonesia then turned into a more powerful political organization, Sarikat Islam (SI). Other important Islamic organizations that have a very large number of members in Indonesia, especially in urban areas and among merchants and intellectuals are Muhammadiyah. Muhammadiyah was founded by traders in the Yogyakarta area. Unlike the Sarikat Islam which had a transformation of orientation into a political party, Muhammadiyah remains focused on charity business or business-oriented but with a strong social orientation. For the example, to improve of quality of education Muhammadiyah established many schools and universities as well as improving the quality of public health by establishing hospitals in various parts in Indonesia. Colonial history that marginalize Islam and the Indonesian Islamic community has encourage the Indonesian Islamic community to interpret the spirit of religiosity as independent of the state. In economy aspect, indepencency is reflected through independent entrepreneurial activities.

The percentage of people who run independent entrepreneurial activities in a country proven by many research has a significant socio-economic benefits (Carree \& Thurik, 2006). Many research tried to enhance our understanding of the factors that encourages entrepreneurial intention and try to reveal any factors that drive or inhibit the emergence of an entrepreneurial activity, so we are able to explain why a person or group 
of people showed many and various independent business activities while others do not (Verheul, et.al, 2012). Kelley, et.al (2012) showed a very big difference between number of entrepreneurial activity that carried out by men than by women. Some research shows people of a particular sub-culture background have a much higher prevalence become entrepreneurs compared to other sub-culture (Edelman et.al, 2010). Age and education are found also influence the decision to become an entrepreneur (Verheul, et al, 2012). More research are needed to reveal the formation process of entrepreneurial intention so we are able to encourage entrepreneurial activity in the communities left behind (Carsrud and Brännback, 2011).

Student's perceptions on entrepreneur as a career option is crucial factor that influence decision that they will take after they graduate later. How a person view of a behavior is crucial impetus for such behavior in the future (Verheul, et al, 2012). The psychology principle that states "people's views do matter" is widely accepted in the scientific empirical study of human behavior. The personal attitude to a profession such as an entrepreneur is influenced directly from the outcome or result of choosing to become entrepreneurs. Beside of believed in providing much higher financial benefits than other professions and, of course, higher risk also, many believe entrepreneurship are able to providing an autonomy and individual freedom (Carsrud and Brännback, 2011)

Entrepreneurial intentions formation model that is relatively widely used by researchers is a model derived from the Theory of Planned Behavior developed by Ajzen (1991); Ajzen, et.al, (2009). From the standpoint of this theory, a behavior that appears in a systematic way does not come from the impulsive and spontaneous decisions that are impulsive and spontaneous, but it has gone through a serial steps of planning, establishment and strengthening of individual intentions and mental readiness. Entrepreneurial activity must be preceded first by the emergence of entrepreneurship intention which further influenced by three variables: attitude, as mentioned above, social norms, and perceived self-efficacy which is a subjective assessment of one's ability to achieve a success as an entrepreneur. Using the model of the Theory of Planned Behavior, we can better understand how and what factors influence the formation of entrepreneurial intentions.

After considering the individual characteristics, entrepreneurial intentions are influenced by environmental conditions in which a person spend daily activities. Social norms are defined as the probability of the people considered important by an individual 
Religiosity and Entrepreneurial Intention

Buddi Wibowo

to approve, support or reject an activity. Social norms are in line with social learning theory which states that a person tends to adopt the behavior displayed by family, close friends, and idols or people he respected. These social norms have a decisive influence on the uncertain situation or unpredictable success, just like the decision to become an entrepreneur. Carsrud and Brännback (2011) showed that social norms are usually operationalized in the form of entrepreneurial experiences in the family, and family support, as some research show, is an important variables in the formation of entrepreneurial intentions.

Other variables that affect the entrepreneurial intention is perceived self-efficacy or perceived behavioral control which is a subjective assessment of one's ability by himself to overcome problems and achieve a success in certain situations. Self confidence is built on an individual self assessment of intelligence, patience, tenacity and flexibility in executing intention into series of entreprenurial action. Self confidence in a entrepreneurial ability is not always mean having the ability in reality, but only limited to the personal assessment of what is possible he could do with the existing capabilities. The results of empirical test shows strong influence of perceived self-efficacy to the intended behavior (Ajzen et.al, 2009).

The interactions between those three antecendent variables of entrepreneurial intention have different impacts depend on situation and person's cultural background. If we follow the division of sub-culture by Hofstede, et.al, (2010) that there are such subculture that emphasizes individualism and on the other side there are sub culture that upholds collectivism. In individualistic sub-culture, attitudes become much more important in shaping the entrepreneurial intentions than the social norm, in contrast to the collective sub-culture, social norms become very important for every individual who has strong orientation towards acceptance, approval and conformity to its environment. Based on the classification Hofstede, et.al (2010), Indonesia can be classified into collective groups or communal culture. Therefore, we can guess the social norms play an important role in the formation of entrepreneurial intentions in Indonesia.

This study will examine the empirical model of the entrepreneurial intentions formation among undergraduate students of the faculty of economics and business. Entrepreneurial intentions formation modeled by using the conceptual framework of the Theory of Planned Behavior in which entrepreneurial activity is preceded by entrepreneurial intention that in its formation process is influenced by three antecendent 
variable: the attitude towards entrepreneurial activity, social norms, and a subjective assessment of the individual's ability to be a successful entrepreneur. Each antencendent variable influenced by a belief, which author hypothesizes religiosity play an important role in the formation of those beliefs. The significant role of religiosity on economic behavior can be tested on the belief relationship with religiosity.

Ajzen, et.al (2009) show that there are strong correlation between entrepreneurial intention and entrepreneurial activities, eventhough some experts critized their model which neglect time interval between intention and its realization. Time interval between intention and realization reflect intention strength. After all, including time interval between intention and realization into model will increase model complexity because entrepreneur or business opportunity arrival can not be predicted and its intensity is different between individual. Developing new business take time through some stages and events that correlated and need different time range. Realization need strong intention but modeling intention with time interval consideration will make very complex.

Entrepreneurial intention determines how a person behaves in a subsequential events and the stages of the process and how they set the pace, direct and harmonize all activities that need to be done in each phase. Understanding of role of entrepreneurial intention in detail in each stage of the emergence of a business still need more research (Laspita, et.al, 2012). One of the theoretical framework that widely used to understand the intention formation process and the manifestation of intention into activities is the Theory of Planned Behavior (TPB) (Ajzen, 1991; Ajzen, et.al. 2009). TPB explains the emergence of intended behavior is affected by three factors: first, a subjective assessment of an individual over a behavior (personal attitude). Secondly, a person's perception that there is social pressure to perform or not a behavior (social norms). Third, the perception of the level of difficulty to perform or to realize an intended activities (perceived behavioral control).

Ajzen, et.al (2009) describe in detail at the indicator level to model the antecedents of intentions by specifying three categories of indicators that are related to one's beliefs over intended behavior. There are three types of individual's belief that influence the intention formation process and strengthen it, first, the belief of the consequences that may arise from an act (behavioral beliefs), second, confidence in the expectations of others (normative beliefs) and the belief in the existence of certain elements that hamper the emergence of certain actions (control beliefs). In aggregate, these beliefs then produce 
Religiosity and Entrepreneurial Intention

Buddi Wibowo

intention factors: personal attitude, social norms, and perceived behavioral control. These three intention factors, in sequence, is a function of behavioral, normative and control beliefs. These intention indicators are a better measure of various aspects represented in a factor. For example, one can see self-employment an attractive option (exist at the level of a factor) but the interest to be an entrepreneur can be driven by many reasons that are vary between individuals: suppose one is interested in becoming entrepreneurs because of the entrepreneurship promise wealth, but some are interested in becoming entrepreneurs because it promises freedom and personal autonomy (indicator level).

Previous research show nearly all of entreprenurial indicator level attributes tend to be male-gendered where the focus of an entrepreneur is to obtain power, money, and that can be called as masculine factors (Carsrud and Brännback, 2011). Verheul, et al (2012) found that both men and women love freedom, personal achievement, job satisfaction and acquisition of other non-economic factors. But women tend to more emphasize non economic factors in deciding a job position than men. Women value more on flexible time to looking for their family than money, women tend to try harder to get a balance between personal career advancement with the interests of their children and family. Budig (2006) found that main motivation of self-employed working women is to balance work with family demands. Shinnar et al.,(2012) shows that women assess aspects of non salary as a more important factor when they are self-employed.

Beside personal attitude, important determinant of entrepreneurial intentions are social norms that are highly influnced by one's normative beliefs. Normative beliefs is the individual's perception that the person or group of people that are considered important by the individual would agree or disagree with his decision to become an entrepreneur (Ajzen et al, 2009). The influence of each normative belief is strengthened when there is a strong motivation to conform the opinion of referant. Verheul et.al. (2009) found that women are affected by social norms to be an entrepreneur. Verheul et.al. (2009) also incorporated the influence of parents who are self-employed and found evidence that men are more affected by the normative role models. Social norms (factor level) is formed from the sum of all the interaction and escalation between normative beliefs and motivation to comply and follow the leader and the referant group.

Bosma, et.al (2012) found that highly respected role models by an individual are usually have same gender. Because entrepreneurs are traditionally dominated by men ( Mueller and Dato-on, 2013), few number of women entrepreneurs who can be a role 
model is a serious factor that influence intentions to become entrepreneurs among women. Hartman and Hartman (2008) find strong role models are very important in the selection of work (occupational intentions) by a woman in a male-dominated professions such as engineering. Barnir et al. (2011) found the same thing in the case of election of a career as an entrepreneur. The existence of gender stereotypes, create role models becomes important role in generating and strengthening entrepreneurial intentions among women students (Shinnar et al., 2012). A person's normative beliefs often encourages women "should" do not behave as an employer and because women tend to always agree (agreeable) with its environment, women are likely to be subject to social norms (Costa, et.al, 2001).

The third determinant of entrepreneurial intention is perceived behavioral control or called by some researchers as the perceived self-efficacy. Control beliefs (indicator level) form the basis of the perceived behavioral control (factor level) where the person already has a personal evaluation that find it is difficult or easy to perform entrepreneurial behavior. Control beliefs related to the presence or absence of opportunities and resources. We can measure it as the multiplication of the respective importance weight control attribute the perceived power of control attribute (Ajzen, 1991). For example, an individual believes that an entrepreneur desperately need management capabilities while individuals assess that he does not have that ability, entrepreneurial intentions will be difficult to grow in him.

Previous research measure perceived behavioral control as an entrepreneurial selfefficacy that is personal belief that he has all the pre-requisite as an entrepreneur (Van Gelderen et al., 2008). Usually self-efficacy is measured as the ability to solve problems, make decisions, manage money, creative, able to make people to be agreed, and being a leader. In the context of the Theory of Planned Behavior model developed by Ajzen (1991), a person's belief in his ability is influenced and shaped in advance by the so-called control beliefs. Ajzen distinguishes internal and external control beliefs. Internal control beliefs are related to belief in personal capability while external control beliefs related to characteristics of the situation that must be handled properly. Belief on personal capacity is not sufficient to establish entrepreneurial intentions if situations and environments that must be faced by a person to start a business is not conducive enough. Shinnar et al (2012) shows external constraints manifest into a barrier that hinder emergence of an act through its effect on the perception of the internal perception of control. Examples of external 
Religiosity and Entrepreneurial Intention

Buddi Wibowo

control beliefs are whether a person perceives financial resources is imperative to start a business or the government's role in facilitating and helping entrepreneurs.

Figure 1 Entrepreneurial Intention Formation Model

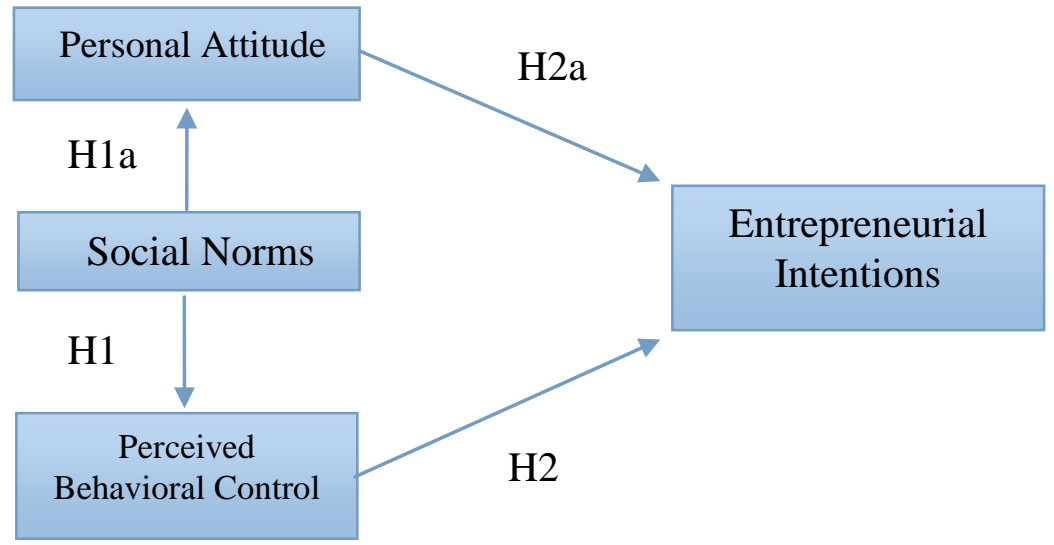

Based on a review of theoretical and empirical test results that have been described above, the entrepreneurial intentions formation among students can be described like the one in Figure 1 and Figure 2. The whole relationship between the constructs summarized in Figure 1 for factor levels and Figure 2 for indicator level.

Figure 2. Entrepreneurial Intention Factors and Beliefs

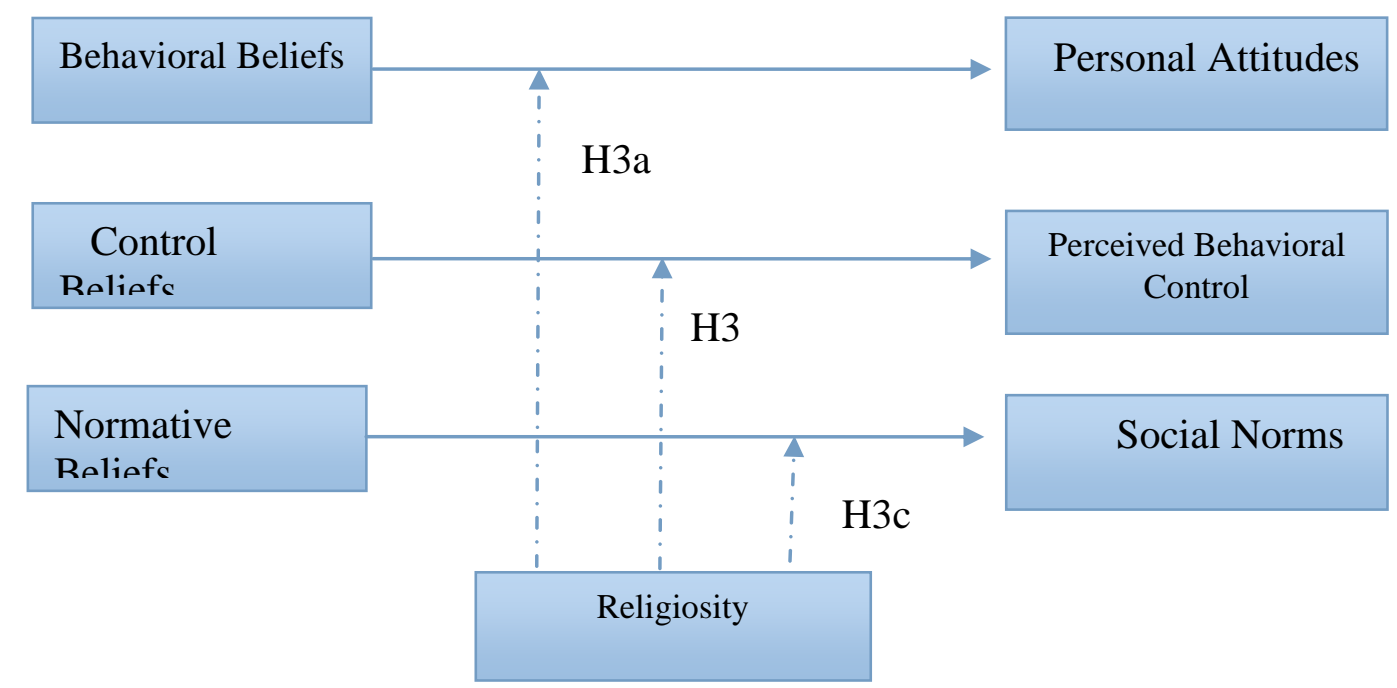

\section{METHOD}

This research was conducted through a survey of 412 undergraduate students of the Faculty of Economics and Business, University of Indonesia. As Mueller (2009), the author chose students at the Faculty of Economics and Business as they can be categorized as a group of people who have an interest in developing a new business (nascent entrepreneurs) who was on the crucial stage of life in deciding the profession or work for 
their future career. As explained by Shinnar et al. (2012), a sample of students is very suitable for the study of entrepreneurship intention because students face directly the problem of career options after graduation and during the process of their study in the university they are continuously considering various career possibilities and career as an entrepreneur is one option they consider.

Survey instruments are measured by the six Likert scale ranging from Strongly Agree to Strongly Disagree. For the level of entrepreneurial intentions determinant factors, the author measure the construct of Theory of Planned Behavior (TPB) with some measure developed by previous researchers. To measure entrepreneurial intentions, this study use Shinnar et al., (2012)) for a personal attitude measurement; Kolvereid and Isaksen (2006) social norms measurement; Mueller (2009) for perceived behavioral control. For personal factors attitude and perceived behavioral control author further specifies behavioral beliefs and control beliefs, which affect both factors sequentially. To measure behavioral control beliefs and beliefs author follows the approach Ajzen, et.al. (2009). Current indicators used for behavioral belief is the product of expectations and value for the items of money, autonomy and further. To measure religiosity, this study follow Deneulin and Rakodi (2011) measurement which is based on personal value of religious belief in day to day activities. Three questions which their answer reflect importance level of religion in a person's view are used to quantify personal religiosity. All respondent of the survey categorized in three group of religiosity according to average value of their answer to those questions: Lowest range of average is not religious group (up to 2 Likert scale), highest range of average is religious group (5 to 6 Likert scale), and those who has average value around 2 to 5 Likert scale is categorized as swing religious person, they have unstable view on importance level of religiosity in daily life.

The study uses structural equation modeling which allows us to test some alternative models by using existing same data in order to examine the role and importance of mediating variables (e.g personal attitude, social norms). The author will use a multigroup analysis in order to compare the results between the two groups that have different view on religiosity.

Structural equation modeling was conducted in two stages $(\mathrm{McD}$ onald \& Ho, 2002). The first phase, we evaluate the adequacy of measurement instruments. The second phase we test the hypothesis of the relationship directly or indirectly between constructs that exist in the model. To measure the discriminant validity of the constructs, 
Religiosity and Entrepreneurial Intention

Buddi Wibowo

confirmatory factor analysis conducted on items entrepreneurial intentions, personal attitude, motivation to comply, normative and perceived behavioral control opinion. Analysis showed the suitability of the models offered (good fit of the suggested models, Hu \& Bentler, 1998). First, SRMR-value (standardized root mean square residual) of 0.03 which is below the cut-off value of 0:08. Second, RMSEA (root mean square error of approximation) is equal to 0,04 are below the cut-off value of 0,06. Third, the CFI (comparative fit index) equal to 0.97 which is above the cut-off 0.95 .

Then, the authors test the measurement invariance of the model, by comparing the measurement models between a group of students who have strong religiosity and group of those who think religiosity is irrelevant factor in daily life decisions. The author conducted two analyzes confirmatory factor analysis separately between those groups. To test significant religiosity effect on entrepreneurial intention formation process, this study compares factor loadings for each factor between estimated models for religious group and not religious group. In order to reveal more detail the religiosity effect on entrepreneurial intention, this study elaborate further the differences in indicators for each entrepreneurial intention factor through regression equations that are estimated by those two groups of students:

Pers. Att $_{i}=\gamma_{0}+\beta_{1}$ Autonomy $_{i}+\beta_{2}$ Money $_{i}+\beta_{3}$ Challenges $_{i}+\beta_{4}$ Life $_{i}+\varepsilon_{i}$

Perc.Beh.Cont $=\gamma_{0}+\beta_{1}$ Competency $_{i}+\beta_{2}$ BusConn $_{i}+\beta_{3}$ Cap $_{i}+\beta_{4}$ Govt $_{i}+\varepsilon_{i}$ where,

Perc.Behav.Contr $=$ Perceived Behavior Control; BusConn $=$ Business Connections; Cap $=$ Capital; Govt $=$ Government Support

\section{RESULTS AND DISCUSSION}

This study observed 412 respondents, which 178 people are those who are categorized as religious people, 134 people who view religiosity is not relevant in daily life, and 100 people who have unstable view on important function that religiosity play in daily life. The female respondents is $58 \%$ of the total sample. All respondent are muslim. Table 1 shows the average entrepreneurial intentions is relatively high at 5.2 on the Six Likert scale. But three determinants of entrepreneurial intention which are Personal Attitude, Social Norms, and Perceived Behavioral Control have relatively low scores, below 4. This result shows all factors of entrepreneurial intentions among students are still not conducive although the entreprenurial intention are relatively high. The religious students group have 
the enrepreneurial intention is much stronger than the group of students who are categorized as not religious. Religious group has higher average entrepreneurial intention and all factors that influence it. The standard deviation of all entrepreneurial intention factors in religious groups are also much lower than the not religious group. Average perceived ability to execute entrepreneurial activities is higher (perceived behavior control) and personal attitude towards entrepreneurial activity is much more conducive and convergent than those who are not religious. Social norms have a score that is almost the same in both groups. The similar cultural background among student in two religios groups led to the similar view of the social norms. These findings are similar to those found by Bosma, et al (2012).

Tabel 1. Descriptive Statistic of Respondents' Responses

\begin{tabular}{|c|c|c|c|c|c|c|}
\hline \multirow{2}{*}{ Full Data } & \multicolumn{3}{|c|}{ Religious Group } & \multicolumn{3}{|c|}{ Not Religious Group } \\
\hline & Mean & $\begin{array}{l}\text { Std. } \\
\text { Dev }\end{array}$ & Mean & Std. Dev & Mean & Std. Dev \\
\hline Entrepreneurial Intention & 5.1 & 1.73 & 5.6 & 0.21 & 4.3 & 1.67 \\
\hline Personal Attitudes & 3.8 & 0.72 & 5.0 & 0.22 & 3.2 & 1.89 \\
\hline Social norms & 3.5 & 0.96 & 3.4 & 0.55 & 3.6 & 1.93 \\
\hline $\begin{array}{l}\text { Perceived } \\
\text { control }\end{array}$ & 3.2 & 0.78 & 5.1 & 0.21 & 3.1 & 1.96 \\
\hline
\end{tabular}

Religious student group has good model fit $(\mathrm{SRMR}=0.05, \mathrm{RMSEA}=0.05, \mathrm{CFI}=$ 0.95), not religious group has lower model fit but also still relatively fit (SRMR $=0.04$, RMSEA $=0.04$, CFI $=0.96$. Figure 2 show SEM estimation result of entrepreneurial intention model for not religious group data.

Figure 3 show the result of the estimation model of the entrepreneurial intention formation with Simultaneous Equation Model on religious student group. From Figure 3 and Figure 4 we can conclude that the entrepreneurial intention antecendent variables, personal attitudes and individual's perception of his ability to succeed as an entrepreneur, are significant with large loading factors. Loading factor of perceived behavior control and personal attitudes for religious student groups are very large (0.87 and 0.89), while those who are not religious only 0.55 and 0.5 . This result suggests that religiosity has a strong effect in shaping perceptions of ability as an entrepreneur and create strong self confidence compare to the irreligious group. This result is reinforced by much more positive the personal attitudes towards entrepreneurial activities in religious group compared to those who are not religious. 
Figure 3 The Estimation Results of Entrepreneurial Intention Formation Model: The Religious Student Group

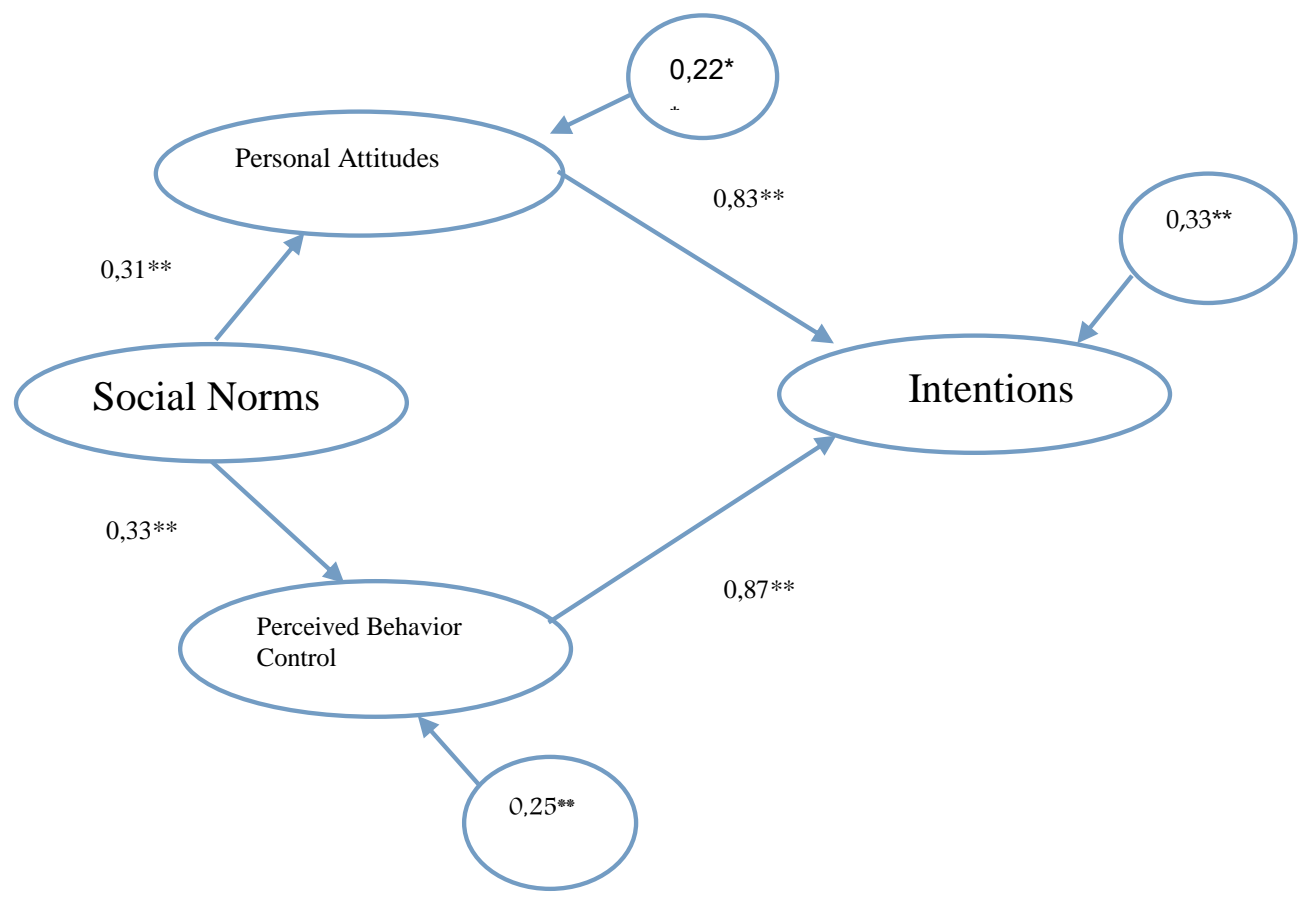

Social norms significantly influences the personal attitudes and perceived behavioral control, both in a group of students who are religious and who are not religious, but the loading factor for personal attitudes and perceptions of entrepreneurial ability are greater in the religious group. Social norms loading factors to perceived behavior control and personal attitudes in religious group are much lower (0.33 and 0.31$)$ than those who are not religious ( 0.78 and 0.71$)$. This shows religious group are not unduly influenced by social norms, so that their perception are conducive to entrepreneur as professional career. Islamic religious teachings urge to choose a profession that provides greater autonomy, the example of the Prophet Muhammad himself was a successful trader, as well as the hadith of the prophet who give high appreciation to trader and entrepreneur can be expected to affect personal religious attitudes. Attitudes arising from religious reasons generally stronger to the influence of the surrounding environment and the opinion of the existing social norms (Torgler, 2006).

This results show that Theory of Planned Behavior (TPB) (Ajzen, 1991), the theoretical framework that widely used to understand the intention formation process and the manifestation of intention into activities, give a clear explanation how entrepreneurial intentions are formed and how religiousity play its role in that formation process. Social norms are not a central factor for religious people. Religious people consider more social 
harmony compared to not religious people but, on the other hand, they have a higher self confident to face a social pressure on entrepreneurial activity (Deneulin and Rakodi, 2010). Their aspiration to follow prophetical teachings of business and trading activity surpass social environment threats.

Figure 4 The Estimation Results of Entrepreneurial Intention Formation Model: The Not Religious Student Group

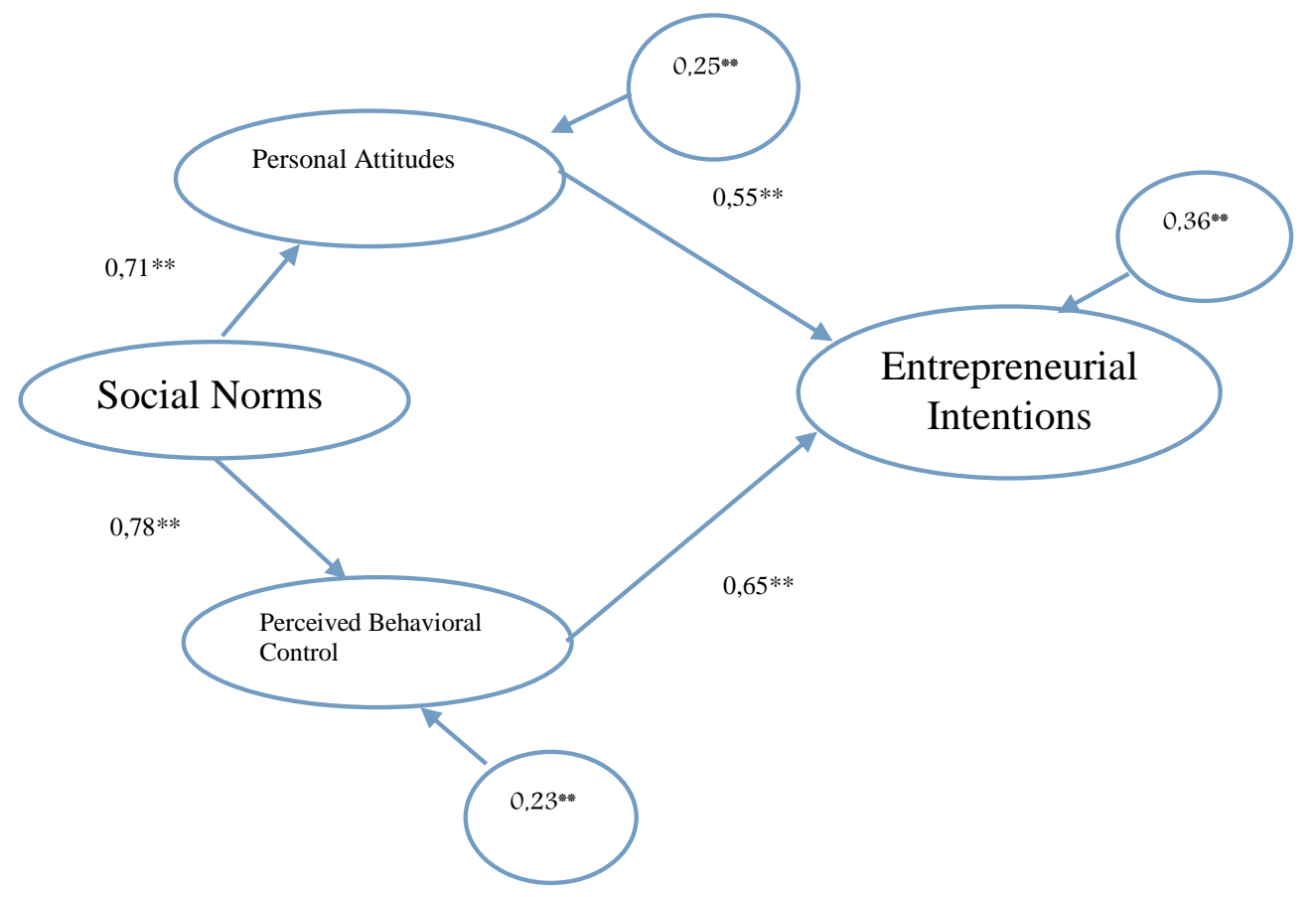

To understand deeper into the differences between the groups of students who are religious and who are not religious on two determinant of entrepreneurial intention, personal attitude and perceived behavioral control, the author examine effect of different religiosity views to those two variables using the model (1) and model (2) described above. The test results are shown in Table 2.

Personal attitude towards entrepreneurial activity is significantly influenced by four indicators: autonomy, money, challenges, and the balance between work and family life. The influence of money and challenges to the personal attitude to become entrepreneurs are similar between religious student groups and irreligious group. It can be seen in almost equal the Religious Beta and Not Religious Beta for these variables. Meanwhile on Autonomy indicators and balance of life, those who are religious have a more greater regression coefficient (beta). This indicates the characteristic differences between the two groups of religiosity where perceptions of autonomy and a balance of life that are offered 
Religiosity and Entrepreneurial Intention

Buddi Wibowo

by entrepreneur profession are far stronger in religious group. The higher the religiosity requires more freedom in making daily decisions (Geertz, 2014).

Tabel 2. Effect of Beliefs on Personal Attitudes and Perceived Behavior Control:

Religiosity Differences

\begin{tabular}{|c|c|c|c|c|c|}
\hline Model Full & \multicolumn{3}{|c|}{ Religiosity } & \multirow[b]{2}{*}{$\mathbf{F}$} & \multirow[b]{2}{*}{ value } \\
\hline & \multicolumn{2}{|c|}{ Prob } & Beta Not Religious & & \\
\hline \multicolumn{6}{|c|}{$\begin{array}{l}\text { Dependent Variable: Personal Attitudes } \\
\text { Indicator: }\end{array}$} \\
\hline $\begin{array}{l}\text { Autonomy } \\
\qquad 0,00\end{array}$ & 0,55 & 0,83 & 0,38 & & 7,73 \\
\hline $\begin{array}{l}\text { Money } \\
0,00\end{array}$ & 0,37 & 0,35 & 0,89 & & 7,19 \\
\hline $\begin{array}{l}\text { Challenges } \\
0,03\end{array}$ & 0,26 & 0,30 & 0,25 & & 3,33 \\
\hline $\begin{array}{l}\text { Balanced Life } \\
0,01\end{array}$ & 0,16 & 0,89 & 0,14 & & 4,07 \\
\hline RSquared & 0,79 & 0,87 & 0,82 & & \\
\hline Durbin-Watson Stat & 2,01 & 2,00 & 2,03 & & \\
\hline \multicolumn{6}{|c|}{ Dependent Variable: Perceived Behavioral Control } \\
\hline $\begin{array}{l}\text { Indicator: } \\
\text { Individual Competenc } \\
0,00\end{array}$ & cy 0,76 & 0,78 & 0,75 & 7,77 & \\
\hline $\begin{array}{l}\text { Business Connection } \\
0,00\end{array}$ & 0,55 & 0,54 & 0,57 & 7,61 & \\
\hline $\begin{array}{l}\text { Capital } \\
0,00\end{array}$ & 0,78 & 0,52 & 0,86 & & 7,23 \\
\hline $\begin{array}{l}\text { Government Support } \\
0,00\end{array}$ & 0,12 & 0,13 & 0,37 & & 7,13 \\
\hline RSquared & 0,73 & 0,81 & 0,69 & & \\
\hline Durbin-Watson Stat & 2,01 & 2,00 & 2,03 & & \\
\hline
\end{tabular}

This result are inline with Alkire (2006) who points out that religious beliefs create positive traits such as trust, honesty, benevolence, and restraint from violence. Religious people tend to give more value consideration on family, social relation and social value. Religious people tend to pursue balanced life between personal development and healthy social and family life (Deneulin and Rakodi, 2010). This result also supports Hofstede et.al (2010) that Indonesian tend to be a collective groups or communal culture that social norms is an important factor in making daily decision but religiousity make people to be more independent, self confident and creative. 
Individual perceptions of the ability to carry out entrepreneurial activities has a very significant difference in the indicator of capital and government support. In the group of not religious students, there is a very strong perception that the ability to be an entrepreneur is influenced by government support and availability of capital. In the group of religious students, we find much lower coefficient on indicators of government support and capital. This shows religiosity tends to open the student minds, so they become more optimistic, independent, and confident in recognizing and executing business models that can be run without enormous capital and the government support, but largely on the creativity and original business ideas. This result give more supports on Deneulin and Rakodi (2010) that religious peple tend to be self confident and risk seeker. The perception of the importance of individual competence and business connections are not too different between the two religious groups. Religiousity influenced-self confident does not change self's perception on competence but it gives a person more confident to face their problems (Alkire, 2006). Both religious and not religious student view business connection as an important factor for entreprenurial activities but religious student tend to have more positive attitudes so they still try hard to start their entreprenurial dream even they have not a business connection at all.

\section{CONCLUSION}

Religiosity influences significantly the establishment of the personal attitude and individual perception of the ability to carry out entrepreneurial activity among undergraduate students. Entrepreneurial Intentions were significantly different between the religious groups and the irreligious group. Religious groups have stronger entrepreneurial intentions with lower dispersion than the group of students who are not religious. Two entrepreneurial intention antecendent variables, personal attitudes and individual's perception of his ability to succeed as an entrepreneur, are significant with large loading factors in religious group and not religious group. This finding indicates the religious group tend to have more conducive perception toward entrepreneur as a profession. Meanwhile the irreligious group has more various aspects of consideration. Religiosity effectively forms personal attitudes and individual assessment of their own abilities to be an independent entrepreneur. Religiosity create self confident with their own decision that mainly based on the Islamic religious teachings that gives the highest appreaciation for a 
Religiosity and Entrepreneurial Intention

Buddi Wibowo

trader, a merchant or an independent entrepreneur. Effect of social pressures are much lower in the religious group.

The results of model estimation shows that social norms as one of entrepreneurial intention formation important determinant variables, although not directly affects entrepreneurial intention, remains a crucial factor in shaping the personal attitude towards entrepreneurial activity and individual perceptions of the ability to succeed as an entrepreneur. Social norms have much greater influence on a group of students who are not religious. Religious student tend to have strong self confidence and put religious teachings as a more important factor than social pressure. At the level indicator entrepreneurial intention, autonomy and balanced life is the most important variables that influence attitudes towards entrepreneurial activity in the religious students group. This findings support the argument about religiosity influences to personal attitude and social norms, that more religious a person will have stonger self confidence and more autonomous. Religious person tend to value more non-monetary benefits of their activities, they value a balanced life and autonomy more valuable than money which is the most important factor for irreligious students. Although the influence of capital and business connections still quite strong, but the religious students have smaller loading factor. This indicates that religiosity once again create stronger self confidence so that they can open up horizons of thought and recognize the various business models to students so they are less dependent on the availability of capital and business connections to start a business.

\section{REFERENCES}

Ajzen, I. (1991). The Theory of Planned Behavior. Organizational Behavior and Human Decision Processes. 50(2): 179-211.

Ajzen, I., Csasch, C., \& Flood, M. G. (2009). From intentions to behavior: Implementation intention, commitment, and conscientiousness. Journal of Applied Social Psychology, 39(6): 1356-1372

Alkire, S. (2006). Religion and development. In D. A. Clarke (Ed.), The Elgar companion to development studies (pp. 502-509). Cheltenham: Edward Elgar.

Barnir, A., Watson, W. E., \& Hutchins, H. M. (2011). Mediation and Moderated Mediation in the Relationship among Role Models, Self-efficacy, Entrepreneurial Career Intention, and Gender. Journal of Applied Social Psychology. 41(2): 270-297. 
Barro, R. J., \& McCleary, R. M. (2003). Religion and economic growth. NBER working paper 9682. Cambridge, MA: National Bureau of Economic Research.

Bosma, N., Hessels, J., Schutjens, V., Van Praag, M., \& Verheul, I. (2012). Entrepreneurship and Role Models. Journal of Economic Psychology. 33(2): 410-424.

Budig, M. (2006). Intersections on the Road to Self-employment: Gender, Family and Occupational Class. Social Forces. 84(4): 2223-2239.

Carree, M., \& Thurik, R. (2006). Understanding the Role of Entrepreneurship for Economic Growth. In Carree, M.A. \& A. R. Thurik (Eds.). The Handbook of entrepreneurship and economic growth. Cheltenham, UK \& Northampton, MA, US: Edward Elgar Publishing Ltd.

Carsrud, A., \& Brännback, M. (2011). Entrepreneurial motivations: What do we still need to know? Journal of Small Business Management, 49(1): 9-26.

Costa, P. T., Terracciano, A., \& McCrae, R. R. (2001). Gender Differences in Personality Traits Across Cultures: Robust and Surprising Findings. Journal of Personality and Social Psychology. 81(2): 322-331.

Deneulin, S., \& Rakodi, C. (2011). Revisiting Religion: Development Studies Thirty Years On". World Development. 39(1): 45-54.

Edelman, L. F., Brush, C. G., Manolova, T. S., \& Greene, P. G. (2010). Start-up Motivations and Growth Intentions of Minority Nascent Entrepreneurs. Journal of Small Business Management. 48(2): 174-196.

Geertz, Clifford. (2014). Agama Jawa: Abangan, Santri, Priyayi dalam Kebudayaan Jawa. Depok: Komunitas Bambu.

Guiso, L., Sapienza, P, and Zingales, L. (2001). People's opium? Religion and Economic Attitudes. Journal of Monetary Economics. 50: 225-282

Habermas, J. (2006). Religion in the Public Sphere. European Journal of Philosophy. 14(1): 1-25. Hartman, H., \& Hartman, M. (2008). How Undergraduate Engineering Students Perceive Women's (and Men's) Problems in Science, Math and Engineering. Sex Roles. 58(34): 251-265.

Hofstede, G., Hofstede, G. J. \& Minkov, M. (2010). Cultures and Organizations: Software of the Mind (Rev. 3rd ed.). New York: McGraw-Hill.

Kelley, D.J., Singer, S., \& Herrington, M. (2012). The Global Entrepreneurship Monitor: 2011 Global Report. Global Entrepreneurship Research Association. Available from: www.gemconsortium.com. Accessed on January 14, 2017. 
Religiosity and Entrepreneurial Intention

Buddi Wibowo

Kolvereid, L., \& Isaksen, E. (2006). New Business Start-up and Subsequent Entry into SelfEmployment. Journal of Business Venturing. 21(6): 866-885.

Laspita, S., Breugst, N., Heblich, S., \& Patzelt, H. (2012). Intergenerational Transmission of Entrepreneurial Intentions. Journal of Business Venturing, 27(4): 414-435

Marx, K. (1844). Contribution to the Critique of Hegel's Philosophy of Right: Introduction. In: The Marx-Engels Reader, Robert C. Tucker (Ed.), Norton, New York, 2nd edition, 1978, 53-65. First published in Deutsch-Franz.osische Jahrb.ucher.

McDonald, R. P., \& Ho, M. H. (2002). Principles and Practice in Reporting Structural Equation Analyses. Psychological Methods. 7(1): 64-82.

Muller, T. (2009). Religiosity and Attitudes Towards The Involvement of Religious Leaders in Politics: A Multilevel-Analysis of 55 Societies. World Values Research. 2(1): 1-29.

Mueller, S. L., \& Dato-on, M. C. (2013). A Cross Cultural Study of Gender-Role Orientation and Entrepreneurial Self-efficacy. International Entrepreneurship and Management Journal. 9(1): 1-20.

Pryor, F. L. (2007). The Economic Impact of Islam on Developing Countries. World Development. 35(11): 1815-1835.

Shinnar, R. S., Giacomin, O., \& Janssen, F. (2012). Entrepreneurial Perceptions and Intentions: The Role of Gender and Culture. Entrepreneurship Theory \& Practice, 36(3): 465-493.

Van Gelderen, M., Brand, M., van Praag, M., Bodewes, W., Poutsma, E., \& van Gils, A. (2008). Explaining Entrepreneurial Intentions by Means of The Theory of Planned Behavior. Career Development International. 13(6): 538-559.

Verheul, I., Thurik, R., \& Grilo, I. (2009). Explaining Preferences and Actual Involvement in Self-employment: New Insights into The Role of Gender. Proceeding at The Academy of Management Conference, August 7-11, Chicago, Ill, USA.

Verheul, I., Thurik, R., Grilo, I., \& van der Zwan, P. (2012). Explaining Preferences and Actual Involvement in Self-employment: Gender and the Entrepreneurial personality. Journal of Economic Psychology. 33(2): 325-341.

Weber, M. (1905). The Protestant Ethic and The Spirit of Capitalism. London: Unwin. 